\title{
After Hajj: Muslim Pilgrims Refashioning Themselves
}

\author{
Kholoud Al-Ajarma
}

Citation: Al-Ajarma, Kholoud. 2021. After Hajj: Muslim Pilgrims Refashioning Themselves. Religions 12: 36. https://doi.org/10.3390/ rel12010036

Received: 1 December 2020

Accepted: 3 January 2021

Published: 7 January 2021

Publisher's Note: MDPI stays neutral with regard to jurisdictional clai$\mathrm{ms}$ in published maps and institutional affiliations.

Copyright: () 2021 by the author. Licensee MDPI, Basel, Switzerland. This article is an open access article distributed under the terms and conditions of the Creative Commons Attribution (CC BY) license (https:// creativecommons.org/licenses/by/ $4.0 /)$.
Faculty of Theology and Religious Studies, University of Groningen, 9712 GK Groningen, The Netherlands; k.a.m.al-ajarma@rug.nl

\begin{abstract}
The Muslim pilgrimage to Mecca (Hajj) is one of the five pillars of Islam and a duty which Muslims must perform-once in a lifetime-if they are physically and financially able to do so. In Morocco, from where thousands of pilgrims travel to Mecca every year, the Hajj often represents the culmination of years of preparation and planning, both spiritual and logistical. Pilgrims often describe their journey to Mecca as a transformative experience. Upon successfully completing the pilgrimage and returning home, pilgrims must negotiate their new status-and the expectations that come with it-within the mundane and complex reality of everyday life. There are many ambivalences and tensions to be dealt with, including managing the community expectations of piety and moral behavior. On a personal level, pilgrims struggle between staying on the right path, faithful to their pilgrimage experience, and straying from that path as a result of human imperfection and the inability to sustain the ideals inspired by pilgrimage. By ethnographically studying the everyday lives of Moroccans after their return from Mecca, this article seeks to answer the questions: how do pilgrims encounter a variety of competing expectations and demands following their pilgrimage and how are their efforts received by members of their community? How do they shape their social and religious behavior as returned pilgrims? How do they deal with the tensions between the ideals of Hajj and the realities of daily life? In short, this article scrutinizes the religious, social and personal ramifications for pilgrims after the completion of Hajj and return to their community. My research illustrates that pilgrimage contributes to a process of self-formation among pilgrims, with religious and non-religious dimensions, which continues long after Hajj is over and which operates within, and interacts with, specific social contexts.
\end{abstract}

Keywords: Hajj; Islam; Morocco; everyday life; self-formation

It was narrated that the prophet Muhammad said: "An 'umra is an expiation for the sins committed between it and the next, and Hajj which is accepted will receive no other reward than Paradise." (hadith) ${ }^{1}$

\section{Introduction}

One day before leaving Mecca in October 2015, Abu Bakr, a Moroccan teacher in his early sixties, prayed: "O God, I pay You farewell with my tongue, but not with my heart." He then left Mecca to return to Morocco, having completed the rites of the Hajj. At the airport in Casablanca, his family waited in anticipation of his safe return. At home, food was prepared for a banquet for family and friends. The living room was cleaned and scented, and plates of sweets were placed on a centrally positioned, large, round table. The preparations at home seemed akin to a purification ritual, making ready the house to welcome the returning pilgrim and the many visitors who would come to congratulate him on his safe return.

In a later conversation with Abu Bakr, he used a telling image to describe the condition of those who perform a pilgrimage, saying: "[Pilgrims] now are like newborn babies: cleansed from sins and full of goodness." He estimated that Hajj precipitates a

1 Hajj al-Mabrūr refers to an accepted pilgrimage (cf. Muslim, book 15, hadith 493). 
major transformation in selfhood and a change on spiritual and moral levels. However, according to Abu Bakr's wife, once pilgrims return home, the real test begins: "would they transform so fully and live up to the morals developed during Hajj and how would they live upon return?"

The Muslim pilgrimage to Mecca (Hajj) is one of the five pillars of Islam and a duty which adult Muslims must perform-once in a lifetime-if they are physically and financially able to do so (Aziz 2001; Bianchi 2004; Peters 1994). During the days of Hajj, pilgrims perform a series of religious and symbolic rites, following the footsteps of the prophets Abraham and Muhammad (cf. Wolfe 1997; Peters 1994; Mawdudi 1982). The Hajj is not only an individual religious undertaking of devotion for Muslims but is also a global annual event that embraces political, social, economic, and intellectual aspects (Ryad 2017). For Muslims, the Hajj often represents the culmination of years of preparation and planning, both spiritual and logistical (cf. Gatrad and Sheikh 2005, p. 133). During Hajj, the behavior of pilgrims should be dominated by piety and morality, by abstention from all temptations, by tolerance when dealing with others and by the avoidance of disputes (Bianchi 2004). The significance of the Hajj and the impact of its rites assume great importance throughout the lives of pilgrims, which can be seen in numerous studies about the Hajj (cf. Bianchi 2004; Wolfe 1997; Peters 1994; Scupin 1982).

As if to mark its personal and social significance, once they have completed the Hajj, pilgrims are given the honorific title al-hạjj, for males, or al-hāajja, for females and the legacy of Hajj manifests itself in their everyday lives. In Morocco, from where thousands of pilgrims travel to Mecca every year, and where I conducted research for eighteen months among Moroccan pilgrims, many of my interlocutors described the Hajj as a transformative experience on both personal and social levels. When they returned from Mecca, my interlocutors spoke about their aspirations to transform and live up to their new status at home. Nonetheless, this desired transformation is not automatically acquired simply by virtue of having completed the pilgrimage. To maximize spiritual benefit, pilgrims must strive to lead pious lives amidst the ambivalences, contradictions and inconsistencies of their everyday lives (cf. Al-Ajarma 2020).

On the worldly level, there are benefits associated with pilgrimage such as good reputation that might impact a pilgrim's social interactions or commercial activities. For example, a businessman who has been to Hajj is expected by community members to be trustworthy and truthful which positively impacts his business (example provided by Abu Bakr, fieldnotes). Pilgrims are often invited as witnesses to marriages and to act as judges in cases of dispute as their opinions and ideas are highly respected in the community (Al-Ajarma 2020). Returning pilgrims, share the community expectations of morally elevated comportment in their daily lives after their return, while, at the same time, admitting a realistic sense of human imperfection. Thus, the question that is often expressed by pilgrims and non-pilgrims alike about the transformative qualities of Hajj remains: what happens on return to the mundane rhythms of the daily life of pilgrims?

In this article, I explore the putative spiritual and social benefits for pilgrims upon their return from the Hajj and particularly address some of the more complex ambiguities they encounter. I do this by making close reference to the testimonies of Moroccans whom I interviewed during long-term fieldwork conducted between the summer of 2015 and the winter of 2017. I argue that the daily lives of those who have performed the Hajj involve an array of practices to which pilgrims are expected to be dedicated. The very fact that people who have performed the Hajj are addressed with the honorific title al-hājj/al-hājja points to expectations of how the experience must, by inference, have changed them. The enactment of what is deemed to be a correct performance of religious duties involves specific ideals or normative expectations, which are dictated by a religious authority or, alternatively, by a faith community's understanding of Islamic tradition. I argue that pilgrims strive to become pious, virtuous, or 'correct' Muslims, as they understand that term, in a process which ultimately becomes the continuous crafting of a religious self. However, this process of crafting a religious self takes place within a context where a pilgrim's morality is 
both displayed and assessed in the public sphere and is not merely a matter of religious observance and private conduct. Pilgrims have to negotiate their new status-and the expectations that come with being a hạjj/hājja-within the mundane and complex reality of everyday life. Therefore, there are many ambivalences and tensions that pilgrims have to deal with upon their return to Morocco. By focusing on the lives of pilgrims after the pilgrimage is completed, this article aims to contribute to the anthropological study of pilgrimage as part of Muslims' everyday life (cf. Schielke 2010). In this research, everyday life is explored through participant observation, by following a group of Moroccan pilgrims mainly through the public and private domains which make up their everyday realms of existence. This study scrutinizes the religious, social, and personal ramifications for pilgrims after the completion of Hajj and how they engage in processes of continuous self-formation that sometimes include moments of success and at other times experiences of doubt brought by the ambiguities, contradictions, ambivalences of everyday life.

\section{The Impact of the Pilgrimage on the 'Everyday Life' of Muslims}

There is a range of academic studies that look at Muslim pilgrimage through various lenses, for instance in relation to tourism (Jamal et al. 2018; Timothy and Olsen 2006), historical encounters (Ryad 2017; Peters 1994, 2017), and globalization (Hyndman-Rizk 2012; Bianchi 2004). ${ }^{2}$ Considerably less work, however, has been performed on the sociocultural dimensions of the Hajj in the lives of Muslims (cf. Clingingsmith et al. 2009; Donnan 1995; Haq and Jackson 2009; McLoughlin 2009). In a study carried out by David Clingingsmith, Asim Khawaja, and Michael Kremer (Clingingsmith et al. 2009) to estimate the impact of performing the Hajj on pilgrims, the authors focus on how performing the Hajj affected religious beliefs and social attitudes of Muslims including feelings of unity with fellow Muslims, increased observance of Islamic practices, such as prayer and fasting, and increased belief in equality and harmony among ethnic groups, in addition to favorable attitudes toward women. In Mass Religious Ritual and Intergroup Tolerance: The Muslim Pilgrims' Paradox, Alexseev and Zhemukhov (2017) explore how the pilgrimage experience can translate into social tolerance toward out groups. Through studying the experiences of Muslims in the Kabardino-Balkaria Republic, the authors argue that pilgrims were more tolerant toward outgroups and open to diverse interpretations of Islam than were similar non-pilgrims. Alexseev and Zhemukhov further discuss the pilgrims' struggles with whether or not their Hajj was accepted by God, leading them to analyze their actions during the pilgrimage. In personal accounts of the Meccan pilgrimage, Moroccans-with whom my study was conducted - speak about how they see themselves as Muslims, individuals who seek spiritual quest and members of a Muslim community following their pilgrimage (cf. Cooper 1999; Donnan 1995). The Hajj is significant in shaping individual moral conduct and bestowing an aura of religious merit on those who successfully completed it (cf. Joll 2011). Christopher M. Joll, in his study of Muslim merit making in Thailand, refers to the Hajj as the biggest merit-making event of a lifetime (Joll 2011, pp. 171-80). Even the title al-hājjj or al-hājja is highly significant on both personal and social levels as form of social, religious and moral capital (cf. Bourdieu 1986; Cooper 1999, p. 93). However, to study how pilgrims bring their understanding of the pilgrimage to reframing the ways in which they engage with religious, social, and cultural practices after the Hajj, in my view, one should examine pilgrims' everyday lives including their behavior, interactions, and other discourses—both personal and social.

2 Other studies have examined the pilgrimage of Muslims in the West, especially in relation to diaspora communities. Some examples include the work of Seán McLoughlin $(2009,2010,2013)$ on the pilgrimage of Pakistani Muslims in Great Britain, the research of Farooq Haq and John Jackson on the Hajj experiences of Pakistani and Pakistani-Australians pilgrims (Haq and Jackson 2009), as well as Carol Delaney's study on the pilgrimage of Turkish migrants in Germany (Delaney 1990). There is also several edited volumes on the Hajj including Hajj: Global Interactions through Pilgrimage edited by Luitgard Mols and Marjo Buitelaar (Mols and Buitelaar 2015) which includes several case studies on the Hajj, the more recent volume Muslim Pilgrimage in the Modern World edited by Babak Rahimi and Peyman Eshaghi (Rahimi and Eshaghi 2019), and most recently, Muslim Women's Pilgrimage to Mecca and Beyond: Reconfiguring Gender, Religion and Mobility edited by Marjo Buitelaar, Manja Stephan-Emmrich and Viola Thimm (Buitelaar et al. 2020). Personal accounts on Hajj (from Morocco) include Abdlellah Hammoudi's A Season in Mecca (Hammoudi 2006) and Hassan Aourid's Riwā'u Makka [The Waves of Mecca] (Aourid 2019). 
A point of departure for the study of everyday life-in general-might be Michel de Certeau's The Practice of Everyday Life (De Certeau 1988), which examines life as it is lived and daily exchanges as a rich source of meaning for scholarly analysis. De Certeau turns focuses on what he sees as the creative poetics of the 'common man' in his patterns of interactions, offering a microanalysis of the daily enactments and renegotiations which people undertake. The study of everyday life focuses on what people do and say in a specific context and how they experience, express, and shape their 'lived religion' (McGuire 2008, p. 12; cf. Schielke and Debevec 2012; Dessing et al. 2013; Ammerman 2007). Understanding religion, Nancy Ammerman argues, requires attention to both the 'micro' practices of everyday interaction, and the 'macro' social structures among which one lives (Ammerman 2007, p. 234). Meredith McGuire follows a similar argument in her work where she focuses on religion as it is practiced, experienced, and expressed by 'ordinary people' (McGuire 2008, p. 12). People's actual everyday experiences, she argues, reflect their personal understanding and daily negotiation of their religion (McGuire 2008). Assuming that individuals continuously engage in making and remaking religion by undertaking religious activities, the religious lives of people are co-constituted by various, sometimes competing, priorities and experiences involving all dimensions of life (cf. Ammerman 2007). This makes everyday life a key tool in the study of religion (Toguslu 2015).

For Muslims, Mecca is the most sacred city on earth, and it has a powerful presence in their everyday life. Many Muslims consider the pilgrimage to Mecca to be the ultimate realization of one's religious development and a way of achieving moral fulfilment or becoming a good, or better, Muslim. Being and becoming a good pilgrim for many people includes the perfection of virtuous behavior, morality, and demonstration of piety (cf. Mahmood 2005). In general, pilgrimage in the everyday life of Moroccans epitomizes the meaning of Islam as "a grand scheme" (cf. Schielke 2010, p. 14). This means that the pilgrimage to Mecca becomes a guideline for life, a spiritual 'watch' and 'compass', providing meaning and direction to everyday concerns and experiences (cf. Tweed 2006). Taking into consideration the complexities in people's everyday lives and their motivations, experiences, practices, and uncertainties in dealing with such complexities, the study of everyday aspects of religion as lived by ordinary people can reveal the "plural, complex, and essentially unsystematic nature of religion" (Schielke and Debevec 2012, p. 3). Since the religious lives of most Muslims are not necessarily governed by an internally coherent set of ethics or by a certainty about the place of religion in both public and private spheres, anthropologists working on Muslim societies have highlighted the prevalence of moral ambivalence, the ways in which individuals deal with conflicting "moral registers" (Schielke 2015, p. 53ff), or "multidimensional" selves (Simon 2014). Thus, struggle, ambivalence, incoherence and failure must receive attention in the study of everyday religiosity (cf. Schielke 2010; Deeb 2015).

In the introduction to the edited volume Straying from the Straight Path: How Senses of Failure Invigorate Lived Religion, David Kloos and Daan Beekers argue that the struggles inherent in everyday life can, in fact, contribute to productive avenues in the processes of ethical formation rather than be seen as setbacks or obstacles to it, given the appropriate, constructive reading of, and learning from, the perceived 'failure'. Therefore, as Kloos and Beekers argue, a comprehensive approach towards the religious subject should include both questions about religious commitment, success, social mobility and progress as well as questions about drawbacks, doubt, and sinfulness. What I find in the narratives of my interlocutors in Morocco is that, although they are sometimes uncertain, doubtful, orindeed-their daily lives show ambivalence, they nonetheless frame their religious lives in terms of an effort to be 'good Muslims' as individuals and members of larger Muslim community. The self-image of a pilgrim is constructed within his or her socio-cultural community, where particular religiously defined ideals of the pilgrimage to Mecca-and of those who perform it-are presented and taught (cf. Sadiqi 2018). A pilgrim is often seen by the community as a person who should apply the highest ideals possible in order to achieve the ideal religious selfhood within the context of their everyday life 
(Al-Ajarma 2020). Nonetheless, a pilgrim is also an individual who has to deal with the ambivalence of everyday life including one's path to piety, drawbacks, doubt, and struggles of 'staying on the right path' or straying from it, as I argue in this article (cf. Beekers and Kloos 2017).

\section{Methods}

The findings presented in this article are based on an ethnographic study that investigates the socio-cultural embeddedness of Muslim pilgrimage to Mecca in contemporary Morocco (Al-Ajarma 2020). The data were collected through extensive multi-site fieldwork that took place between July 2015 and January 2017. Participant observation was conducted to research the presence of Hajj in everyday social relations and micro-practices before the journey and after their return home. In addition to participant observation, in-depth interviews were held with people who have been on Hajj. The stories produced in interviews were used to analyze pilgrims' use of different discourses in narrations on the meaning of Hajj, while participant observation allowed the study of how concrete acts and unsolicited references to Hajj point to shifts in pilgrims everyday lives. I examine how pilgrims reflect on the aftermath of their pilgrimage by looking at how a pilgrim is expected to behave and how pilgrims reflect on their daily struggles and deal with them. For the purpose of this article, I use testimonies from ten pilgrims who reflect on their post-Hajj experiences and four non-pilgrims who reflect on their experiences with pilgrims. ${ }^{3}$

\section{The Return of Pilgrims and Expectations of and from Them}

During my fieldwork in Morocco, my interlocutors often describe their journey to Mecca as a religious and spiritual experience so great that it was sometimes "beyond comprehension" (Amina, pilgrim from Fes). In their narratives, many pilgrims echoed the words of Rashid, a pilgrim from Mohammedia, who told me:

Pilgrimage is a great experience; it is an opportunity to cleanse oneself from sins

... When one returns home, he is like a new born baby; one purified from sins

$\ldots$ It is an opportunity for a new start and a renewed fait...

In this sense, the Hajj is a rite of passage that marks transition to a new life cleansed from sins, a life that starts upon return from the pilgrimage (cf. Donnan 1995). In conversations with Moroccans, many people spoke to me about their expectations that those who have been to Mecca come back spiritually rejuvenated, displaying a new enthusiasm for a religious life upon return home. In the words of Zahra, a fifty-three-old woman from Fes: "When pilgrims return from Hajj, they come back similar to a blank sheet of paper ... They should be careful what to write on that sheet..." The image of the pilgrim as a tabula rasa suggests that all past misdeeds are obliterated, purged and forgiven, so that the returned pilgrims begin their spiritual journey again, with no sins weighing them down. The ideas of rebirth and purification are central to the spiritual transformation which the returning pilgrim hopes to undergo and their social prestige and legitimacy that comes with it (cf. Eickelman and Piscatori 1990).

According to Zakariya, a tailor from Fes, when pilgrims return home, they focus on having the 'correct' character traits deemed by tradition to be associated with a good pilgrimage, a topic that recurred frequently in discussions of pilgrimage with Moroccans. In conversations related to the Hajj, my interlocutors often focused on describing what is expected of a pilgrim, both in terms of external behavior and expressions of piety. Interior piety is largely linked to the idea of cultivating, and having cultivated, the sense of a close relationship with God, a feeling highly prized by pilgrims. Upon return from Hajj, many

3 The eleven Moroccan pilgrims whose narratives are used in this article (in the order they are presented): Abu Bakr (61, teacher from Mohammedia), Amina (57, teacher from Fes), Rashid (64, businessman from Mohammedia), Zakariya (56, tailor from Fes), Samiya (62, homemaker from Fes), Osama (68, former government employee from Fes), Yasir (fabric shop owner, from Fes), Ali, (39, engineer from Casablanca), Lubna (37, former factor worker, from Mohammedia), and Hisham (67, former teacher, from Safi). The three non-pilgrims: Sarah (45, shop owner, from Ouezzane), Hassan (23, student, from Safi), Nisrin (29, job unknown from Casablanca), Najla (59, teacher from Mohammedia). 
pilgrims manifested a desire to achieve closer proximity to God, an inner state achievable through the devout performance of religious duties. This was illustrated in my interactions with pilgrims in Morocco, when I asked what, if anything, had changed in their lives since returning from Hajj. First, those returning to Morocco after performing the Hajj told me that the pilgrimage resulted in transformations that were manifested in behavior related to religious rituals, most notably in the realm of prayer and other kinds of religious activity. According to Samiya, a pilgrim in her sixties from Fes:

Before going on Hajj, I used to pay less attention to my religious duties . . . I could not wake up for fajr prayers [at dawn], for example, and rarely fasted outside of the month of Ramadan ... Now, I make sure to pray on time, wake up for fajr prayers, fast regularly and help others ... A pilgrim should never lie, should not cheat, and should be a good neighbor ... [A pilgrim] should stay on the right path [al-șirāt al-mustaqīm]...

My interlocutors often spoke about striving towards what they considered to be a pattern of Islamic perfection. Although they may oscillate between this ideal and the realities of daily life (cf. Beekers and Kloos 2017), observable evidence suggests that they tried to be faithful to their pilgrimage, and "stay on al-șirạt al-mustaqim [the straight path]," to quote the words of Samiya. ${ }^{4}$ For example, as asserted by Samiya, prayers are an important part of a pilgrim's daily routine; the morning prayer is a central focus in the schedule of waking and preparing for work. Pilgrims take on additional daily prayers and religious obligations, including voluntary fasting and reciting the Qur'an. In general, pilgrims assert a conscious belief that they have become more mindful of religion in their daily life.

For my interlocutors, becoming a pilgrim was largely concerned with the development of a new moral self, one that differentiates more closely than before between what is good and bad, right and wrong, sacred and profane. This new zeal can be heard in daily speech, with pilgrims intensifying their use of religious interjections, such as in-sha'-Allāh (God willing) and $m \bar{a}$-sh $\bar{a}$-Allāh (God has willed it), which they widely use in their daily conversations (cf. Migdadi et al. 2010). ${ }^{5}$ Such interjections serve to indicate a prevailing disposition to think, speak and act within a religious framework. Pilgrims also exhibit a determination to perform other acts, including extending hospitality and giving alms to the poor. Other aspects of external behavior, operating on a lower level, but nonetheless having significance for pilgrims, include smiling, being kind to others, solving disputes, and adopting a positive demeanor in public. Such conduct is not exclusively the province of the devout, but pilgrims seemed to see it as a daily manifestation of spiritual grace acquired, or intensified, during Hajj.

Pilgrims try to protect and preserve their new spiritual state of purity while, at the same time, navigating their daily lives and interactions with others. Society may expect to perceive the outward signs of inward change. However, the ideal of 'staying on the straight path', nonetheless, is met with various challenges and realities of everyday life that require decision making: "should one take advantage of the new status and ask others to address him or her with the honorific title of al-hājj or al-hājj?" (Samiya); "Should a pilgrim conduct business which might entail religious compromise, such as the inability to perform prayers on time?" (Abu Bakr); and "Should a pilgrim lie, pretend, or cheat to benefit his business?" (Rashid). Pilgrims voiced these challenges and others as part of their everyday experiences after Hajj. In my conversations with the three pilgrims-and other Moroccans-I tried to unpack how they dealt with these challenges.

4 Al-șirāt al-mustaqim or the straight path is mentioned in the opening chapter of the Qur'an in the form of a supplication prayer from humans to God: "Guide us to the straight path: the path of those You have blessed, those who incur no anger and who have not gone astray" (Qur 'an 1, 6-7). Historian Michael Cook notes that șirăt in Arabic is only ever used in a religious context. Also it has no plural form, indicating that there can be only one sirāt which is living through the way to God (Cook 2000, p. 25).

5 Both in-shā'-Allāh and mā-sha' '-Allāh refer to that what God wishes can come true (Migdadi et al. 2010). 
The answer for the first of the three questions - that of honorifics-is somewhat debatable among my interlocutors. While some of my interlocutors considered it "normal" to use the title of al-hājj or al-hājja as a sign of respect and honor when addressing a person performed Hajj, other people questioned the "normality" of such naming. Nisrin, a young Moroccan woman from Casablanca, for example, told me that respect and honor should be given to a person for their moral behavior and good deeds regardless of their having performed the Hajj. She told me the story of a friend of her mother, who upon returning from Hajj, demanded to be called al-hājja. Nisrin previously addressed the women as $k h \bar{a} l t \bar{\imath}$, a term that means maternal aunt and is applied-as a mark of respect-to older women. Nisrin questioned the demand of the older woman and insisted that she was being respectful when referring to the woman as khāltī. According to Nisrin, the woman wanted deferential recognition for her status and was seeking social recognition for religious merit, pursuing prestige rather than spiritual recognition. More than once, Nisrin said, the woman called attention to her pilgrimage, by bringing the topic up when she visited relatives; for example, when she made reference to the cold weather, she insisted on comparing it with the dry heat of Mecca during her pilgrimage. When I asked Nisrin if she called the woman by the title al-häjja, she answered: "Allāh yismahli [May God forgive me], but when I see her, I call her khāltì on purpose ... I can see it on her face that she does not like it!" The fact that Nisrin began her answer with Allāh yismahli, however, was an indication that she believed her behavior towards her mother's friend might not be appropriate, considering the latter's age and social status as a female pilgrim. To some extent, being recognized as a pilgrim still carries high social significance among Moroccans, although the greater frequency of completion of the Hajj has introduced a modern ambivalence to the title, albeit a relatively muted one.

When Moroccans discuss the issue of ascribing high status to pilgrims, many people draw a clear distinction between religion, culture and tradition. Abu Bakr, for example, questioned the established practice of automatically giving titles to pilgrims in Morocco. For him, the practice of naming is more of a cultural than religious practice. When asked about the title al-häjj by which he is known, he commented:

When the Prophet performed the Hajj in Mecca, no one called him al-hāajj Muhammad. His companions also performed the Hajj. But no one says al-hāajj Ali, al-hāajj Umar or $a l-h \bar{a} j j$ Uthman ... Those were the leaders of the Muslim community; yet none of them was called al-hāijj.

The reason a person should perform pilgrimage, according to Abu Bakr, is simply that God commands pilgrimage, and, therefore, it is not obligatory to be given the title $a l-h \bar{a} j j$ upon their return from Mecca. Zakariya expressed a similar view:

When someone prays, he performs an obligation. Yet, he would not be called al-mușalli [the one who prays]. When he fasts, he performs an obligation, yet he would not be given the title of al-șa 'im [the one who fasts]. Pilgrimage is the same; it is an obligation and those who perform it are lucky and hopefully God accepts their pilgrimage; but there is no need for them to be called al-hājj ... I did not ask people to call me al-hājj. However, everyone started calling me al-hāajj upon return from Mecca ... Now, my work colleagues, my family members, my cousins, and neighbors all call me al-hāijj.

Both Abu Bakr and Zakariya believed that it was a decision made by the community to confer upon them the honorific title of one who has completed the Hajj and it was not something the pilgrims themselves should ask for (cf. Buitelaar 2018). Nonetheless, both men are known in their community as al-hāijj. During my fieldwork, I met with the two men numerous times on different occasions, always hearing their relatives, family members, and others calling them al-hājj. Sometimes the real name of a person even overlapped under the title $a l-h \bar{a} \hat{a} j$, such as $a l-h \bar{a} j j$ Osama, a former government employee from Mohammedia who was always addressed with the title $a l-h \bar{a} j j j$ among his collogues followed by his family name. 
The respect and honor showed towards pilgrims comes with expectations of piety and respectful behavior with others as to justify the honor which others should show them. However, the honorific title rings hollow when the transformation expected seems unfulfilled and members of the community are reluctant to ascribe the title to flawed individuals. One way my interlocutors reflected on the difference between expectations and reality was shown in humorous accounts of pilgrims returning from Hajj. For example, Sarah, a woman from Ouezzane, told me this joke while talking about returning pilgrims:

There was a Moroccan man who returned from Hajj. He went to a nearby shop in his neighborhood where he was a regular customer. He asked the owner to show him the record of his debt in the shopkeeper's loan notebook. The man was excited thinking that al-hājj was about to pay the debt. He opened the notebook and pointed to one page. The pilgrim said: "Where is my name?" The shop owner answered: "Here it is, al-hājj!." The pilgrim nodded his head and said: "Well, now you can write 'al-hāajj' in front of my name!"

This humorous account illustrates the expectation of the shop owner of a returning pilgrim paying his debt and then being met with the irony that the pilgrim was only concerned about the title. The joke hints at the challenge of change following a pilgrimage and the possibility of there being unchangeable characteristics. Hassan, a young man from Safi, told me another humorous account of a similar nature:

There was an old lady who told a lot of lies. Her children said: "Let's send her to Hajj so that she will be decent and stop lying." So she went to Hajj and returned. Her children waited for her at the airport and upon welcoming her back they asked her: "Al-hājja, how was your travel?" She said: "Oh, what can I say? The airplane broke down and was stationed in the middle of the sky; we had to get out and push it to move!"

The use of humor in both accounts can be interpreted as a means of challenging the boundaries of social expectations (cf. Tamer 2009). The jokes indicate how pilgrims were looked upon or treated upon return. This technique interrogates the 'perfect' image some people attribute to pilgrims. Although people might have religious, social and personal expectations from pilgrims and effectively demanding higher standards of a pilgrim than of others, pilgrims are first and foremost humans who might or might not change following their pilgrimage experience. Pilgrims might aspire to stay on the right path, yet they have to negotiate their journey-on that path—-through the ambivalence of their everyday life.

\section{Ambivalences of Everyday Life, Staying on the Right Path and Straying from It}

When I asked my interlocutors about the changes they witnessed in their actions after they returned from Mecca, they sometimes struggled to scrutinize their own behavior. Those around pilgrims, however, including family members and friends, in my experience, were more vocal in actively assessing the behaviors and religious conduct of the returned pilgrim. For example, Najla, the wife of Abu Bakr, clearly remembered her husband's post-hajj behavior:

Before al-hāijj left for Mecca, at the airport, he cried and asked for forgiveness for every moment of anger and every unjust action during our life together ... I felt like he was paying the last farewell ... We all cried and to myself I thought that he would return as $a l-h \bar{a} j j$, a truly transformed person! ... I wondered: 'can he live a life without sins? ... Will he live up to his new title, al-hạajj?'

Remembering the return of her husband to Morocco, especially the first few weeks, Najla described him as the kindest she had ever known him. "How long do you think that lasted?" Najla asked me. She then answered her own question: "Three months!" Najla recalled the words of her husband upon his return from Mecca:

He told me that being on Hajj reminded him of the Prophet, especially of the deeds of the Prophet who was a gentle man, a kind and a loving husband, and a good father and neighbor ... [My husband] wanted to be a loving husband 
just like the Prophet ... And he was! He was the perfect husband; never angry, always smiling and speaking nicely and gently ... For three months! After three months, he returned to his old self ... He is not a bad person, but he easily gets angry, screams, and gets irritated often ... I have to say, though, those three months [immediately following his return] were the best months of our twenty-five years of marriage...

In the three months that followed her husband's return from Mecca, Najla recognized Abu Bakr as "truly al-hājj;" a pilgrim who was spiritually transformed. The husband worked to demonstrate piety and reverence and by evincing qualities such as openmindedness and readiness to be a good husband. This change is a state largely brought about through the pilgrim's own efforts. However, the transformation, in this case, was not held to be permanent, revealing that the experience of pilgrimage alone is often considered insufficient, of itself, to bring about a total and lasting change. For Najla, some pilgrims appear not to have internalized the moral status of pilgrimage deeply enough, with the result that they find it difficult to sustain their desired transformation following their return to their daily lives after the pilgrimage (cf. Spiro 1997, p. 3). Therefore, the new moral status, acquired after pilgrimage, becomes a site of struggle for the returning pilgrim, a fact observed within the family, and evaluated by those closest to the pilgrim. Rashid, the pilgrim from Mohammedia, expressed this dilemma clearly when he told me:

When people go on Hajj and return, their behavior might change between themselves and God with more prayer, fasting and almsgiving. However, what is between themselves and people might not change a lot ... Pilgrims are just humans; they might return to treat people badly, cheat, or gossip ... [That's part of] a human's daily life!

Reflecting on the daily struggles pilgrims face, my interlocutors often compared the daily life in Morocco with the pilgrimage experience itself. Abu Bakr, for example, reflected on his experience by saying:

Over there [in Mecca] you're occupied with worship and with very little distraction you would think that you would lead a pious life once you return home... And then you come here where you have to go to work again, deal with people on a daily basis, sometimes you have no time ... At first when you come back you are still in that [pious] mood; but with daily busy life, you return to the routine ...

What Abu Bakr described was coherent with his wife's observation of the change in his character following his pilgrimage. His return to the rhythms of everyday life was shaped less by the effects (or absence of them) of a spiritual transformation brought about by the pilgrimage than by the routines of work, family, and social life. Abu Bakr's experience was somewhat similar to that of Rashid who told me:

In Mecca I felt so peaceful; I was only occupied with worship from morning to night; I would pray, read Qur'an, visit religious sites ... Then when I came back, I wanted to stay on the straight path ... I had to go to work again, to deal with people at work, the day is busy between work, family, and other responsibility. In Mecca, I didn't have any responsibility as such apart from worship ... At first, I was more committed; still connected with my Hajj experience ... But being back in real life is difficult...

For Abu Bakr and Rashid, committing to the morals they aspired to achieve when they were in Mecca including honesty, trust, and 'staying on the right path' was difficult given the "realities of everyday life, struggles, and having to deal with people at home and at work" (Rashid). What the two men described was the taxing transition from the intense experience in Mecca, dominated exclusively by religious pursuits, to the return home, to the multi-dimensional demands and rhythms of everyday life, such as work, family life, and social responsibilities. Rashid compared the difficulty of staying on the right path, with 'the trust' that what is mentioned in the Qur'anic verse "... We did offer the trust [of 
reason and volition] to the heavens, and the earth, and the mountains yet they refused to undertake it and were afraid of it; mankind undertook it - they have always been inept and foolish" (Qur'an 33: 72). He believed that the ideals a pilgrim aspires to reach are similar to the 'trust 'mentioned in the verse: so heavy and unattainable that even heavens and earth refused to carry that trust and also, in a vein similar to the verse, he believed that being foolish and straying from the right path is part of "man's nature."

Although Rashid believed that it is almost impossible to stay on the right path, he believed that there are ways to be a good pilgrim including fully applying the teaching of the Qur'an and the Prophet's instruction for moral action (cf. Schielke 2009). He told me that he aspired to do good deeds, fast more, and be a good husband as examples of being a good Muslim in general and a good pilgrim in particular. He, however, admitted that it is hard for everyone to live up to the standards of being a good pilgrim, and therein lie the ambiguous consequences of pursuing the ideals of religious expectations. As Najla put it: "At the end of the day, a pilgrim is only human; humans do the right and the wrong. They might try not to, but it is difficult." Thus, the benefits of pilgrimage in terms of its legacy are held to be equivocal. Therefore, some pilgrims-and people around them-recognize that to fail and err is human and thus they moderate their expectations of pilgrims.

It is, of course, pilgrims themselves who must deal with their own sense of failure. They may provide different explanations for the change, or lack of change, in themselves after Hajj. Osama, a pilgrim from Fes, for example, told me that he believed that one's character does not significantly change after Hajj but that the outcome of Hajj depends on one's upbringing, tarbiya. What Hajj adds, according to Osama, is a reminder of moral behavior that people sometimes overlook though the distractions of everyday life. He, nonetheless, insisted that, although a pilgrim might return to his old habits, the change in his or her heart would remain consistent after Hajj. In his words: "after Hajj, a pilgrim's heart is filled with faith [yi mar bil-īmān]." To overcome the sense of failure, Osama visits Mecca regularly to perform the minor pilgrimage, 'umra. He told me that he has been to Mecca at least twenty times since he performed the Hajj. For Osama, and several others of my interlocutors who can afford the expenses of " $u m r a$, the minor pilgrimage seemed to be a way to deal with their sense of failure by visiting Mecca and "renewing their faith" (Osama).

I noticed during my fieldwork that the difficulties or tensions that emerge when pilgrims try to live up to the religious ideals can be age specific. Many older pilgrims had fewer daily responsibilities and thus could assign more time to religious activities such as fasting and diligent prayers. Ali, for example, told me that his father, who was retired, had more time during the day to dedicate to religious duties such as prayers and voluntary fasting. He, however, as a younger man, had more distractions within the structures of his daily life. He, nonetheless, argued, that within his community, people tend to be more lenient in judging the behavior of younger people than that of older ones whom they expect to show pious behavior.

Many of interlocutors acknowledged that it was their struggle to lead pious lives after the Hajj that led them to realize that impossibility of always remaining on the right path. Yasir, a fabric shop owner from Fes, emphasized the fact that "it would be impossible for any Muslim-including pilgrims-not to commit sins; only God is Perfect." Here's how Ali, an engineer from Casablanca, put it:

People have diverse opinions when it comes to what is right and what is wrong ... I know I make mistakes ... I really try not to; but at the end of the day we are not angels ... We all make mistakes ... I think it was Imam Shafi'i who said, 'I believe my opinion is right with the possibility that it is wrong and I believe the opinion of those who disagree with me is wrong with the possibility that it is right...'

Expressions such as "Only God is Perfect and "We are not angels" were used by Yasir and Ali to demonstrate the continuous struggle and tension between complying with religious obligations and wanting to engage in mundane activities. The acknowledgement 
of failure, in my view, was part of the two men's 'self-fashioning' as pious Muslims (cf. De Koning 2017, p. 48). Also in the same volume, Thijl Sunier asserts that failure and virtue are ambiguous, semantic categories subject to debate and contestation (Sunier 2017, p. 113). It could be argued that explicitly acknowledging their sense of failure can be a 'technique of the self' through which pilgrims formulate and rechannel that sense of failure as a learning moment (cf. Beekers and Kloos 2017; Sunier 2017).

When my interlocutors acknowledged their failure in the process of ethical formation due to the ambiguities of their everyday lives, they spoke of the different ways they cope with this sense of failure by finding consolation in religious or social activities. Some pilgrims, for example, told me that they managed to find spiritual encouragement by engaging in activities that were performed within their social networks which were established during the pilgrimage itself. According to Lubna, a young woman from Mohammedia:

During the pilgrimage, I became friends with some Moroccan women I met in Mecca. When we returned, I stayed connected with a few of them ... Sometimes we visit each other and often we exchange messages via WhatsApp ... We remind each other of the time we spent in Mecca and support each other if needed $\ldots$

Hisham, an older man from Safi, shared similar accounts to that of Lubna, stating that he also was able to establish networks of friends-during Hajj-beyond his old social networks with whom he regularly connect. Other pilgrims find support in social activities such as gatherings of family and friends. Ali, for example, is a member of a group that plays music and sings religious-themed songs at events and gatherings such as weddings or other celebrations. He told me that the activities of the band and practice meetings positively influenced his life. He also told me about a friend who acted similarly by producing artworks including drawings and paintings which he then shared with friends or exhibited in halls where people could see them. These activities, Ali argued, "could strengthen one's incentives to perform religiously motivated acts in the midst of the struggles of life."

Reflecting upon his experience and 'testifying' about moments of struggle-and sometimes failure-contributed to his understanding of his self-development and maybe, as he reflected it, enhanced the presentation of his religious self (cf. Buitelaar 2018). ${ }^{6}$ In other words, recognizing and responding to one's lack of capacity to realize certain ideals becomes a mode of self-cultivation.

To sum up, failing to live up to ideals and to perform all one's religious obligations can be partly excused, or at least counterbalanced, by referring to one's laudable intentions and motivations, suggesting that failure itself is not due to carelessness or a lack of faith, but some flaw inherent in the human condition. I suspect that many pilgrims felt the need to emphasize in this verbal way their heartfelt commitment in order to present themselves as legitimate religious adherents who take their religious obligations seriously, even if their performance falls short of what was desired.

\section{Conclusions}

In this article, I have discussed how pilgrims, who have fulfilled the fifth pillar of their faith, relate to a particular religious ethos that they are expected to embrace, negotiate, and practice within the social spaces they inhabit. On the basis of my observations and conversations with Moroccans, both pilgrims and their family members, friends and other non-pilgrims, I have argued that, just like everybody else, the everyday lives of pilgrims are laden with ambiguities and contradictions. There are several contradictions between, on the one hand, how a pilgrim is expected to behave in a religious moral register and, on the other, the reality of his or her actual behavior and daily interactions with others. Furthermore, as a major event in the lives of Muslims, the Hajj does not only affect the millions of pilgrims who actually make the journey, but also their friends and relatives who vicariously experience the occasion through them. Therefore, the relationships between

6 Buitelaar, personal communication (15 October 2019). 
pilgrims and their social networks after the Hajj are likely to change, in complex and varied ways, based on their new religious and social status.

While my Moroccan interlocutors recognized that pilgrimage to Mecca can have certain transformative properties on moral and ethical self-formation of returning pilgrims, they do not always consider the outcome to be perfect or lasting. Thus, my research reveals that the construction of a virtuous self and piety is far from straightforward in the everyday lives of pilgrims. Despite the aspirations and manifestly sincere efforts made by returned pilgrims, there is a general realization-among my interlocutors-that the performance of the Hajj is no guarantee, per se, of a life transformation and an elevation to a higher religious standard. It seems, from the research, that the lived experiences of pilgrims are rather marked with complexities and ambivalences-all of which are rooted in human imperfection and conditioned by the social context in which pilgrims live.

The narratives of pilgrims indicate this complexity in their struggle to remain on the right path of piety and straying from that path. The complexity can also be seen in the responses of family members and friends to the newly elevated pilgrim which reveal some social responses when expectations placed on pilgrims are not fulfilled. The humorous anecdotes targeting the pilgrim who remains unreformed operates with wit and mild satire to indicate a community acceptance, and maybe gentle mockery of, the failure to live up to the expectation of total moral transformation. Similarly, the denial of the deferential title of hāijj or hạajja to those whose conduct disappoints can act as a corrective, a puncturing of hubris of those who prize their title above their religious virtue; such acts also subtly assert the importance of the proper comportment of the hạjj or hạjjja by withholding the title from those who seem not to merit the honor.

To sum up, if piety, religious self-fashioning and conviction constitute one aspect of what pilgrims strive to achieve, post-Hajj, imperfection, uncertainty, and ambivalence are undeniably competing elements of the everyday lives they live. Self-perceived failure is, in many cases, part and parcel of religious practice and experience. To navigate, or negotiate the complexities of life as it is lived, while still maintaining a sense of striving for spiritual improvement, is a laudable religious pathway according to many pilgrims. However, it is also the case that to accept human frailty and yet sustain a religious endeavor, even if not perfectly realized, could provoke a sense of failure, which might, in turn, militate against that sustained religious practice. A possible reconciliation of these conflicting positions seems to be a recognition that spiritual improvement is the target, rather than perfection, and this allows pilgrims to navigate the ambiguities of daily life as they find them.

Funding: This research was funded by the Netherlands Organization for Scientific Research (NWO) grant number: 360-25-150.

Informed Consent Statement: Informed consent was obtained from all subjects involved in the study.

Conflicts of Interest: The author declares no conflict of interest.

\section{References}

Al-Ajarma, Kholoud. 2020. Mecca in Morocco: Articulations of the Muslim pilgrimage (Hajj) in Moroccan Everyday Life. Ph.D. thesis, University of Groningen, Groningen, The Netherlands.

Alexseev, Mikhail A., and Sufian N. Zhemukhov. 2017. Mass Religious Ritual and Intergroup Tolerance: The Muslim Pilgrims' Paradox. Cambridge: Cambridge University Press.

Ammerman, Nancy Tatom, ed. 2007. Everyday Religion: Observing Modern Religious Lives. Oxford: Oxford University Press.

Aourid, Hassan. 2019. Riwā'u Makka. [The waves of Mecca]. Beirut: al-Markaz al-Thakafi.

Aziz, Heba. 2001. The journey: An overview of tourism and travel in the Arab/Islamic context. In Tourism and the Less Developed World: Issues and Case Studies. Edited by David Harrison. Cambridge: CABI Publishing, pp. 151-60.

Beekers, Daan, and David Kloos, eds. 2017. Straying from the Straight Path: How Senses of Failure Invigorate Lived Religion. New York and Oxford: Berghahn Books.

Bianchi, Robert R. 2004. Guests of God: Pilgrimage and Politics in the Islamic World. New York: Oxford University Press.

Bourdieu, Pierre. 1986. The Forms of Capital. In Handbook of Theory and Research for the Sociology of Education. Edited by John Richardson. Translated by Richard Nice. New York: Greenwood, pp. 241-58. 
Buitelaar, Marjo. 2018. Comparing Notes: An Anthropological Approach to Contemporary Islam. Inaugural Lecture. Groningen: University of Groningen.

Buitelaar, Marjo, Manja Stephan-Emmrich, and Viola Thimm, eds. 2020. Muslim Women's Pilgrimage to Mecca and Beyond. Reconfiguring Gender, Religion and Mobility. London: Routledge.

Clingingsmith, David, Asim Ijaz Khwaja, and Michael Kremer. 2009. Estimating the Impact of the Hajj: Religion and Tolerance in Islam's Global Gathering. The Quarterly Journal of Economics 124: 1133-70. [CrossRef]

Cook, Michael. 2000. The Koran: A Very Short Introduction. Oxford: Oxford University Press.

Cooper, Barbara. 1999. The Strength in the Song: Muslim Personhood, Audible Capital, and Hausa Women's Performance of the hajj. Social Text 60: 87-110.

De Certeau, Michel. 1988. The Practice of Everyday Life. Translated by Steven Rendall. Berkeley: University of California Press.

De Koning, Martijn. 2017. 'I'm a Weak Servant': The Question of Sincerity and the Cultivation of Weakness in the Lives of Dutch Salafi Muslims. In Straying from the Straight Path: How Senses of Failure Invigorate Lived Religion. Edited by Daan Beekers and David Kloos. New York and Oxford: Berghahn Books, pp. 37-53.

Deeb, Lara. 2015. Thinking Piety and the Everyday Together: A Response to Fadil and Fernando. Hau: Journal of Ethnographic Theory 5: 93-96. [CrossRef]

Delaney, Carol. 1990. The 'Haij': Sacred and Secular. American Ethnologist 17: 513-30. [CrossRef]

Dessing, Nathal M, Nadia Jeldtoft, Jørgen Schøler Nielsen, and Linda Woodhead, eds. 2013. Everyday Lived Islam in Europe. Ashgate Ahrc/Esrc Religion and Society Series. Farnham: Ashgate.

Donnan, Hastings. 1995. Pilgrimage and Islam in Rural Pakistan: The Influence of the 'Haj'. Etnofoor 8: 63-82.

Eickelman, Dale F, and James Piscatori. 1990. Muslim Travellers: Pilgrimage, Migration, and the Religious Imagination. London: Routledge.

Gatrad, Abdul Rashid, and Aziz Sheikh. 2005. Hajj: Journey of a lifetime. BMJ 330: 133-37. [CrossRef] [PubMed]

Hammoudi, Abdellah. 2006. A Season in Mecca: Narrative of a Pilgrimage. Cambridge: Polity Press.

Haq, Farooq, and John Jackson. 2009. Spiritual Journey to Hajj: Australian and Pakistani Experience and Expectations. Journal of Management, Spirituality \& Religion 6: 141-56.

Hyndman-Rizk, Nelia. 2012. Pilgrimage in the Age of Globalisation: Constructions of the Sacred and Secular in Late Modernity. Newcastle upon Tyne: Cambridge Scholars Publishing.

Jamal, Ahmad, Razaq Raj, and Kevin A Griffin, eds. 2018. Islamic Tourism: Management of Travel Destinations. Boston: CABI.

Joll, Christopher M. 2011. Muslim Merit-Making in Thailand's Far-South. Muslims in Global Societies Series 4; Berlin: Springer. Available online: https://www.academia.edu/1975047/Muslim_Merit-making_in_Thailands_Far-south_Springer_2011 (accessed on 10 November 2020).

Mahmood, Saba. 2005. Politics of Piety: The Islamic Revival and the Feminist Subject. Anthropology Online. Princeton: Princeton University Press.

Mawdudi, Sayyid A. 1982. Origin and Significance of the Hajj. Available online: http://www.islamicity.com/mosque/hajj/ letsbemuslims.htm (accessed on 15 November 2020).

McGuire, Meredith B. 2008. Lived Religion: Faith and Practice in Everyday Life. Oxford: Oxford University Press.

McLoughlin, Sean. 2009. Holy Places, Contested Spaces: British-Pakistani Accounts of Pilgrimage to Makkah and Madinah. In Muslims in Britain: Identities, Places and Landscapes. Edited by Peter Hopkins and Richard Gale. Edinburgh: Edinburgh University Press, pp. 132-49.

McLoughlin, Sean. 2010. Muslim Travellers: Homing Desire, the Umma, and British-Pakistanis. In Diasporas: Concepts, Identities, Intersections. Edited by Kim Knott and Sean McLoughlin. London: Zed Books, pp. 223-229.

McLoughlin, Sean. 2013. Organizing Hajj-going from Contemporary Britain: A Changing Industry, Pilgrim Markets and the Politics of Recognition. In The Hajj: Collected Essays. Edited by V. Porter and Liana Saif. London: The British Museum Press, pp. 241-52.

Migdadi, Fathi, Muhammad A. Badarneh, and Kawakib Momani. 2010. Divine Will and its Extensions: Communicative Functions of maašaallah in Colloquial Jordanian Arabic. Communication Monographs 77: 480-99. [CrossRef]

Mols, Luitgard, and Marjo Buitelaar, eds. 2015. Hajj: Global Interactions through Pilgrimage. Mededelingen van het Rijksmuseum voor Volkenkunde Leiden. Leiden: Sidestone Press, vol. 43.

Peters, Francis E. 1994. The Hajj: The Muslim Pilgrimage to Mecca and the Holy Places. Princeton: Princeton University Press.

Peters, Francis. E. 2017. Mecca: A Literary History of the Muslim Holy Land. Princeton: Princeton University Press.

Rahimi, Babak, and Peyman Eshaghi, eds. 2019. Muslim Pilgrimage in the Modern World. Chapel Hill: University of North Carolina Press.

Ryad, Umar, ed. 2017. The Hajj and Europe in the Age of Empire. Leiden: Brill.

Sadiqi, Fatima. 2018. Female Perceptions of Islam in Today's Morocco. Journal of Feminist Scholarship 11: 48-60.

Schielke, Samuli. 2009. Being Good in Ramadan: Ambivalence, Fragmentation, and the Moral Self in the Lives of Young Egyptians. The Journal of the Royal Anthropological Institute 15: S24-40. Available online: www.jstor.org/stable/20527687 (accessed on 20 November 2020). [CrossRef]

Schielke, Samuli. 2010. Second Thoughts on the Anthropology of Islam. ZMO Working Papers. Available online: http://zmo.de/ publikationen/WorkingPapers/schiel-ke_2010.pdf (accessed on 20 November 2020).

Schielke, Samuli. 2015. Egypt in the Future Tense: Hope, Frustration, and Ambivalence Before and After 2011. Bloomington: Indiana University Press. 
Schielke, Samuli, and Liza Debevec, eds. 2012. Ordinary Lives and Grand Schemes: An Anthropology of Everyday Religion. New York: Berghahn Books.

Scupin, Raymond. 1982. The Social Significance of the Hajj for Thai Muslims. The Muslim World 72: 25-33. [CrossRef]

Simon, Gregory M. 2014. Caged in on the Outside: Moral Subjectivity, Selfhood, and Islam in Minangkabau, Indonesia. Honolulu: University of Hawai'i Press.

Spiro, Melford E. 1997. Gender Ideology and Psychological Reality: An Essay on Cultural Reproduction. New Haven: Yale University Press. Sunier, Thijl. 2017. Moral Failure, Everyday Religion and Islamic Authorization. In Straying from the Straight Path: How Senses of Failure Invigorate Lived Religion. Edited by Daan Beekers and David Kloos. New York: Bergbahn, pp. 107-24.

Tamer, Georges. 2009. Humor in Der Arabischen Kultur. Berlin: Walter de Gruyter.

Timothy, Dallen J, and Daniel H. Olsen. 2006. Tourism, Religion, and Spiritual Journeys. London: Routledge.

Toguslu, Erkan, ed. 2015. Everyday Life Practices of Muslims in Europe. Leuven: Leuven University Press.

Tweed, Thomas A. 2006. Crossing and Dwelling: A Theory of Religion. Cambridge: Harvard University Press.

Wolfe, Michael. 1997. One Thousand Roads to Mecca: Ten Centuries of Travelers Writing about the Muslim Pilgrimage. New York: Grove. 